\title{
Progressive atheism: how moral evolution changes the god debate
}

\section{J. L. Schellenberg, Bloomsbury, 2019, 200 pp, \$15.36 (paper), \$42.70 (hardback)}

\section{Egan Wynne ${ }^{1}$. Justin McBrayer ${ }^{1}$}

Accepted: 8 January 2021 / Published online: 29 January 2021

(c) The Author(s) 2021

Progressive Atheism is one of Professor J.L. Schellenberg's recent contributions to philosophy of religion. In a nutshell, the book argues that human moral evolutionthe shift in moral attitudes and beliefs over history-has implications in philosophy of religion (61). In particular, he thinks that recent progress in our moral thinking about what counts as a good person and what counts as morally permissible action strengthen the case for atheism. Moral evolution ought to lead to religious evolution.

Here's why. If we were to ask someone in the 1600 s what the ideal human father would look like, we'd get a very different answer than if we asked someone that same question today. Out are things like being stern, strong, objective, and prone to cold-blooded calculations of utility. In are virtues like empathy, kindness, and cooperation. We don't have to go back to the 1600s to see this: the behavior of 1950s role models should be enough to give you pause. Go watch a 1950s sit com or an early James Bond movie, and you'll see protagonists behave in ways that are now rightly considered sexist, abusive, and morally abhorrent.

Professor Schellenberg argues that this sort of moral progress makes the idea of God "more admirable and less believable" (xi). Clear moral vision allows us to turn perfect-being theology back on itself: since we have a more accurate grasp of perfection, we'll see that classical descriptions of God fall short of the mark (144). In return, he says, we'll also see that traditional arguments for atheism are strengthened considerably. If the standards for perfection go up, then it becomes even more obvious how this world falls desperately short. In place of theism, we should rally around a progressive-and open-minded-version of atheism.

Egan Wynne

eawynne@fortlewis.edu

Justin McBrayer

jpmcbrayer@fortlewis.edu

1 Fort Lewis College, Durango, USA 
We don't think the maneuver works. Despite being a clear and accessible piece of philosophy that makes some important contributions to the literature, the central move of the book falls short. In that sense, Progressive Atheism makes little progress. Our review offers a synopsis and an appraisal of the project.

Synopsis: The book is divided into ten chapters. These ten chapters could be divided into three sub-projects: chapters $1-3$ constitute the negative project, chapters 4-8 constitute the positive project, and chapters 9-10 deal with objections and implications related to progressive atheism.

The first three chapters set the conceptual stage by dismantling the current, antagonistic defense of atheism that is represented in the so-called New Atheism of the last couple of decades. Professor Schellenberg's critique of New Atheism has two legs, one psychological and one philosophical.

On the psychology side, Professor Schellenberg draws a distinction between being pro-God and anti-God, where being anti-God is associated with having a negative evaluation of the content of God and/or wishing that there were no such being. This is an important distinction, he thinks, because much of the recent work on atheism has been plagued by anti-God sentiments. Being anti-God is, itself, an intellectual mistake: "everyone who understands this idea of God should, in the relevant sense, be pro-God" (14). We should want there to be a God even if we think there isn't one. Yet just as an economist's pro-capitalism attitude can affect the quality of her research on markets, so too can a philosopher's antiGod attitude affect the quality of his research on God's existence. Beware of the philosopher who concludes, "There is no God, and I'm happy about it!" And yet anti-God sentiment is widespread. Why?

Professor Schellenberg limns five different sets of psychological errors that lead to anti-God sentiments and atheological dead-ends: (1) being pro-naturalism, (2) being turned off by the idea of an ad hoc addition of God to one's ontology, (3) confusing "vanilla" theism with one of the lived theisms in the world (e.g. Pentecostal Christianity), (4) assuming that God-if such there be-is responsible for the imperfections in our world, and (5) a carry-over of negative sentiments from one's former theistic commitments. Each of these psychological avenues produces a sort of anti-God bias that infects otherwise earnest attempts to establish the truth of atheism.

On the philosophy side, Professor Schellenberg undermines the argument from naturalism to atheism. He grants the major premise: if naturalism is true, theism is false. However, he cautions against this shortcut to atheism by remaining skeptical of the minor premise. "The naturalistic shortcut is questionable because it is questionable whether human inquiry is mature enough to allow us to know what the naturalist claims to know" (43). Human intellectual immaturity should make us skeptical of naturalism, and hence we can't use naturalism as a premise in our case for atheism.

The second section of the book (chapters 4-8) represents Professor Schellenberg's positive project. Very briefly, this section surveys the evolution of human moral thinking, uses these moral insights to update the concept of God, and then deploys this revised concept of God in three arguments for atheism. Each argument is a redux of a classical argument for atheism: the hiddenness argument (chapter 6), 
a specific argument from evil focusing on horrors (chapter 7), and a specific argument from evil focusing on violence (chapter 8).

On the issue of moral progress, Professor Schellenberg argues that over time we have both expanded the scope of who or what we find morally considerable (e.g. most of us now extend moral consideration to at least some non-human animals) and loosened existing moral prohibitions (e.g. outside of Uganda, most of us no longer think that gay sex should be punished with death). These changes amount to progress in our moral thinking (and not merely change) as evidenced by the wide overlap in application by disparate moral theories (e.g. the utilitarian and the Kantian both agree that it's wrong to kill people for having homosexual sex) and the nearly universal intuition among contemporary thinkers that the moral views that sanctioned the burning cats for fun (e.g.) were morally worse than those we have at present.

Given this moral evolution, we can no longer think of God in traditional ways. For example, it no longer makes sense to think of God as relationally distant or unempathetic. We need to update our understanding of what God would be like: God is not properly understood as a solitary male, a distant father, or a capricious king (89). God wouldn't burn cats for fun. Instead, he is properly understood as benevolent and empathetic and so much more.

Cue the final twist of the positive project: if we rid our concept of God of the outdated moral virtues and instead think of God as empathetic and interested in relational love, the traditional arguments for atheism become more persuasive. Understanding God in this way makes it clear why God would seek a relationship with everyone and hence eliminate nonresistant nonbelief in his existence. That is supposed to strengthen the argument from divine hiddenness. And understanding God in this way makes it clear that God wouldn't allow individuals to suffer horrors in their lives and wouldn't create a world with this much violence, no matter the consequences. The crucial gist is that our moral evolution allows us to see that unsurpassable empathy functions as a side constraint limiting God's consequential calculations about compensating goods that he might get from horrors or violence.

The final section of the book consists of two chapters that seek to defuse objections and clarify the implications of progressive atheism. The two most important objections are what he calls the "Hidden Reasons Objection," a reference to skeptical theism, and the "Similarity Constraint," the idea that if God were to create, he would inevitably create a world that is quite similar to our own. As to the first, Professor Schellenberg insists that he has not engaged in "noseeum" reasoning: he doesn't conclude that there are no good reasons for God to allow an evil just because he doesn't see one. Rather, he concludes that in principle there could not be reasons for God to allow certain evils. As to the second, Professor Schellenberg thinks that the similarity constraint is an unwarranted assumption which should be rejected, since there are likely to be many possible worlds that are radically dissimilar to the actual world and yet actualizable by God. Rejecting it makes the theist's case weaker and the atheist's case stronger.

Chapter ten closes the book with a discussion of the implications of progressive atheism. Determining that there is no omni-God of the sort posited by theism is the beginning, not the end, of religious and supernatural investigation. Professor 
Schellenberg encourages philosophers to shift their work to options like developmental theism and ultimism rather than continuing to work on versions of traditional theism. There is room, as Professor Schellenberg has argued before, for skeptical religion.

Appraisal: If you work in philosophy of religion and have not read Professor Schellenberg, you've missed out on one of the clearest and most fair-minded thinkers of our time. This book lives up to that standard. If Professor Schellenberg is progressive in anything, it is in bringing a clear and unbiased approach to philosophy of religion.

Further, the book provides an interesting diagnosis of the problems that plague popular discussions of atheism. The so-called New Atheists are explicitly anti-God. Indeed, this is a large part of popular atheist discourse. Professor Schellenberg is right to call these strategies atheological dead ends, since they "terminate with an error about the nature of God rather than with the justified belief that God does not exist" (19). We note that there is a similar worry on the theistic side: many debates about God are plagued by pro-God sentiments, where interlocutors are so caught up on the fact that it would be good for God to exist that they fail to evaluate objectively the arguments under consideration. In our view, much of what counts as theistic apologetics suffers from this defect. This is a valuable diagnosis of what can go wrong in philosophy of religion and one that all of us should note well.

It's also true that Professor Schellenberg's focus on the actual implications of atheism are novel and carefully defended. Atheism need not be a dead-end, negative conclusion. It might be true that theism is false, but other sorts of religious propositions might be true. As opposed to popular atheistic thinking, Professor Schellenberg does not think that atheism entails that all religious life or religious thought are irrational or obsolete. Professor Schellenberg is one of the few philosophers to take this option seriously and argue for it at length (e.g. see the final book in Professor Schellenberg's trilogy, The Will to Imagine).

Despite this praise, we think the central move of the book falls flat. Two of the three arguments on which he focuses are not new. At best, he offers additional reasons to endorse premises in those arguments for atheism. The third argument is new but suffers from the same flaws as the other two arguments for atheism. In both cases, we think the philosophical force of his considerations doesn't add anything to the dialectic. The focus on moral evolution doesn't offer new arguments for atheism or strengthen old ones. If anything, the focus on moral evolution and human epistemic limitations indirectly strengthens undermining objections offered by skeptical theists and others.

With respect to the first complaint, the argument from divine hiddenness and a species of the argument from evil (namely the argument from horrors) aren't new. The third, more novel argument, is the argument from violence. Professor Schellenberg argues that reflection on our moral evolution either provides new reasons or at least strengthens old ones to endorse the major premise in each argument. The argument from violence, he claims, is genuinely new, given the distinction he draws between suffering and violence. The idea is that our moral evolution has brought us to the point where we now see violence itself as morally problematic whether it's connected to suffering or not. For all three arguments, Professor Schellenberg claims 
that once we're focused on the fact that God would be maximally relational, empathetic, etc., then it is easier to see why he would not allow nonresistant nonbelief, horrors, or violence in the world.

But Professor Schellenberg goes further. He thinks that reflection on our moral evolution commits us not just to endorsing the premises but also ruling out exceptions to them in advance. In a discussion about all three of the improved arguments, he writes that.

If God existed there would be no nonresistant nonbelief; a maximally empathetic God who was maximally well acquainted with horrors could not be sufficiently motivated to bring about goods requiring the permission of horrors; and if God existed, then should there be any world at all it would be some world other than our violent world. Look closely at each at these premises and what you'll see is that if it's true, then there isn't a good reason for God to permit the item in question (167-148).

But, of course, if the unconditional versions of these premises are true, we need a reason to endorse them beyond a reminder that we now think of empathy as a moral ideal. Good philosophers have assumed that God would be maximally empathetic and knowledgeable about horrors and violence and yet wondered whether premises like these were true. Does the fact that I allow my son to endure the pain of an inoculation show that I'm not maximally empathetic? No. The same seems to hold for God. And so, we're off to the races with the usual discussions of whether God needs evils to accomplish certain ends, what moral constraints God must act within, etc. Nothing new here.

To see what we mean, let's take a closer look at one of the three arguments for atheism: the argument from horrors. Professor Schellenberg grants Marilyn McCord Adams' definition of horrors as instances of "suffering that gives surviving victims or perpetrator a reason, not necessarily a conclusive reason, to think their lives are not worth living" (110). Why does our moral evolution give us special or additional reason to think that God would not allow horrors in the world? Professor Schellenberg thinks that our moral evolution teaches us that "even if there are goods that require the permission of horrors, none could possibly rise to that level" for an unsurpassably empathetic God (119). But why should we believe that? What we need is an argument that current human moral thought implies (or at least suggests) that there are inviolable side constraints on the actions of a morally perfect being. Professor Schellenberg provides no such thing.

And that's not surprising. Think of it this way: if current human moral thought had this implication, it would also imply that both moral consequentialism and moral pluralism are false! And yet Professor Schellenberg seems to embrace this implication. He writes that "unsurpassable empathy would function as a constraint on the sort of good situation that could possibly be good enough" (118). Given that roughly $25 \%$ of professional philosophers endorse a consequentialist view of ethics 
(e.g. utilitarianism), this is a high cost. ${ }^{1}$ Are all of these philosophers really ignorant of the moral value of nonviolence and empathy?

On the second complaint, Professor Schellenberg wields his skepticism in an inconsistent way. In some places, he deploys skepticism to generate some of his central conclusions. Elsewhere, he decries the skepticism of others, saying that we know enough to draw an inference about the issue at hand. And there doesn't seem to be a principled way to draw a line between the cases. For example, as we noted above, he uses skepticism to block the inference from naturalism to atheism: "The naturalistic shortcut [to atheism] is questionable because it is questionable whether human inquiry is mature enough to allow us to know what the naturalist claims to know" (43). In other words, there's a lot we don't know, and reflection on our cognitive limitations should provide a dose of epistemic humility significant enough for us to remain agnostic on the truth of naturalism. That's why we can't use naturalism as a premise in an argument for atheism.

In contrast to this, when Professor Schellenberg draws all sorts of moral conclusions on the basis of intuition and the shifts of human moral thought over the millennia, he dismisses skeptical objections. Instead, he argues that we can almost certainly count our change in moral thinking as progress because he thinks that it is incredibly unlikely we will revert to old manners of moral thought:

That careful moral thinking will go back to what I assume we've grown beyond - say roasting cats for fun or strangling people in public —is even less likely than the smart techies going back from today's computing devices to the Commodore 64 (72).

This might be true, but what's good for the goose is good for the gander. Given this change of moral attitudes across time, we can just hear Richard Joyce and other moral anti-realists invoking skepticism to block Professor Schellenberg's inferences about moral side constraints. They might say-in parallel to what Professor Schellenberg says to the naturalist - that the moral shortcut to atheism is questionable because it's questionable whether human inquiry is mature enough to allow us to know what the moralist claims to know. Perhaps the real lesson of one thousand years of moral change is that we should be skeptical of absolute moral prohibitions of the sort Professor Schellenberg proposes. Or, more radically, perhaps the lesson is that morality is an illusion.

All of these issues get worse when Schellenberg turns to talk about the "similarity constraint." Basically, he argues that we should do away with our belief that God would have to create a world like the one we inhabit because assuming this is unwarranted. But this ends up being very helpful for the theist, since we are now free to take our skepticism to new heights. If God could create a world totally unlike ours, why couldn't he also be securing also sorts of goods we are totally unaware of by allowing certain evils?

The problem, of course, is that the focus on the long history of mistakes in human reasoning (in science, morality, or anything else) is a shot in the arm for epistemic

\footnotetext{
${ }^{1}$ See D. Bourget and D. J. Chalmers, "What Do Philosophers Believe?" in Philosophical Studies 170:3 (2014): 465-500.
} 
humility. And in the realm of philosophy of religion, it's just the sort of humility championed by the skeptical theist to undercut arguments for atheism (something that Professor Schellenberg grants: 147). Broadly, the skeptical theist claims that we should be agnostic about whether God has reasons for allowing certain evils, since God could have reasons for allowing evil that we cannot know. Given this sort of skepticism, we should remain agnostic on the question of whether, for example, "a maximally empathetic God who was maximally well acquainted with horrors could not be sufficiently motivated to bring about goods requiring the permission of horrors" (118). And if we're skeptical about premises like that, then none of the revamped arguments for atheism go through.

Finally, we want to note something about the progressive nature of Professor Schellenberg's progressive atheism. Progressive atheism is the denial of the existence of God paired with open-minded religious investigation and a cultivation of moral virtues. Professor Schellenberg even ends the book with the hope that in the future "atheism will quite naturally be paired with high moral expectation" (175).

We note-and Professor Schellenberg concedes - that there is no argument or evidence for this optimism. There's no conceptual link between atheism and moral realism and no behavioral link between professing atheism and acting virtuously. Just as critics of atheism make a mistake by citing Hitler and Stalin as reasons to think atheists must be (or are likely to be) immoral, so too, defenders of atheism make a mistake if they assume that atheists must be (or are likely to be) moral. So, at best Professor Schellenberg provides an aspiration or vision for what atheism might become, rather than a reason to think that such a future is likely to be.

Open Access This article is licensed under a Creative Commons Attribution 4.0 International License, which permits use, sharing, adaptation, distribution and reproduction in any medium or format, as long as you give appropriate credit to the original author(s) and the source, provide a link to the Creative Commons licence, and indicate if changes were made. The images or other third party material in this article are included in the article's Creative Commons licence, unless indicated otherwise in a credit line to the material. If material is not included in the article's Creative Commons licence and your intended use is not permitted by statutory regulation or exceeds the permitted use, you will need to obtain permission directly from the copyright holder. To view a copy of this licence, visit http://creativecommons.org/licen ses/by/4.0/.

Publisher's Note Springer Nature remains neutral with regard to jurisdictional claims in published maps and institutional affiliations. 